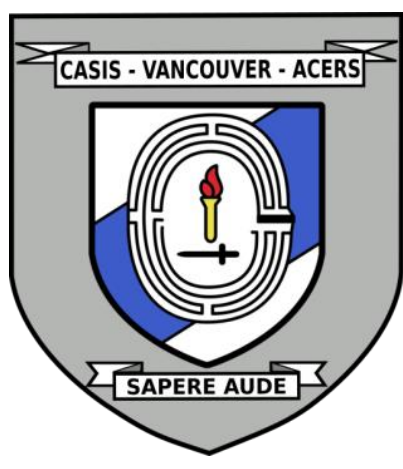

\title{
RE-ENVISIONING CANADA AS A PENINSULA STATE
}

Date: November 22, 2021

Disclaimer: This briefing note contains the encapsulation of views presented by the speaker and does not exclusively represent the views of the Canadian Association for Security and Intelligence Studies.

\section{KEY EVENTS}

On November 22, 2021, Dr. Tsuyoshi Kawasaki, Political Science Professor at Simon Fraser University, presented Re-Envisioning Canada as a Peninsula State at the 2021 CASIS West Coast Security Conference. The presentation was followed by a question and answer period with questions from the audience and CASIS Vancouver executives. The key points discussed included reimagining Canada's geopolitical position in the world of politics, future implications for Canada as the Arctic ice continues to melt, and long-term implications that call for immediate attention.

\section{NATURE OF DISCUSSION}

\section{Presentation}

The central theme during Dr. Kawasaki's presentation was the conceptualization of Canada as a peninsula state as the Arctic ice continues to melt and great powers strategize in the area. Dr. Kawasaki also emphasized the importance of Canada being prepared for unprecedented situations as its geopolitical position in the world of politics changes.

\section{Question Period}

During the question and answer period, Dr. Kawasaki discussed the current involvement of smaller countries in the Arctic issues, as well as future great power dynamics. 


\section{BACKGROUND}

\section{Presentation}

Dr. Kawasaki began his presentation by arguing that with the opening of the Arctic Ocean, Canada is becoming a peninsula state. This is the first time Canada is facing different great powers in the Arctic, such as Russia, China, and the United States. Considering that Canada is not a great power in this new strategic environment and that the said states are now taking action, Canada should be prepared for new situations to arise.

There is an old assumption that the Pacific, Atlantic, and Arctic Oceans are all separate; however, peninsula states need to think about the connectivity between all ocean fronts. These connections have long-term implications. For example, once the Arctic Ocean opens completely, one can only wonder what Canada's priority will be in terms of resource allocations. Historically, Canada has focused only on the Atlantic side, but what would happen once the Arctic Ocean opens further?

Dr. Kawasaki highlighted the importance of being prepared for these new changes and noted that the North Atlantic Treaty Organization (NATO) has prepared the NATO 2030 strategic concept, in which they argue it is imperative for the organization to prepare for China to become a political challenger. This new reality forces us to think beyond traditional ways and how to link the Pacific and the Atlantic. Thinking of Canada as a peninsula state is a foundational concept to help us understand this new situation.

A peninsula state has two or more ocean fronts and is connected to a great power land neighbour. Some examples include Italy, France, and Korea, which even though they are all peninsula states, all have unique strategic imperatives to deal with given their geopolitical features. Dr. Kawasaki also argued that although Canada is not a peninsula state at the moment, it should be aware of strategic dynamics specific to peninsula states, as the melting of the Arctic ice is forcing it to become one.

There are three kinds of strategic dynamics in the game of great power politics related to peninsula states:

- Oceanfront connections

- Wedge-driving tactics

- Sovereignty and abandonment security dilemma

The Journal of Intelligence, Conflict, and Warfare Volume 4, Issue 3 
Canada and China are dealing with transpacific issues; however, one ought to ask what happens if the Arctic issues become part of their negotiation agenda. For example, what would happen if China proposed a reciprocal endorsement on claims of internal waters over the South China Sea for China and over the Northwest Passage for Canada? This is only one example of many potential strategic moves that could happen in the future. NATO is already talking about these potential linkages, but Canada does not seem to be discussing any of these issues and is only focused on the Atlantic side, so one can only wonder what this means for Canada.

In terms of wedge-driving tactics, external powers such as Russia, China, or other oceanfront countries are trying to damage the Canada-US alliance. They do not go after the US because it is a greater power and Canada is an easier target, and they are also aware that Canada and the US positions regarding the Northwest Passage are different. External powers often go after smaller power countries. Dr. Kawasaki emphasized the importance of Canada not becoming the weak link in the Western alliance system, while also noting that perhaps it is time for Canada to begin their own wedge-driving tactics.

There are unique dynamics that would surround Canada as a peninsula state. Something that Canada needs to think about is that it does not have a national security council, which helps to centralize the country's position. Other longterm implications that Canada should start thinking about include strategic priorities, resources allocations, and institutional configurations.

\section{Question Period}

During the question and answer period, Dr. Kawasaki noted that Arctic issues go beyond Russia, China, or the US. Japan, Iceland, Sweden, and Norway, for example, are also looking at these issues and paying attention to all the moves that other countries are making, even if they are not involved in any strategic moves. Their main focus has been on non-strategic security issues, such as environmental issues. Nevertheless, great power politics has returned worldwide.

Canada has been in a fortunate position since most confrontations have been in the Western Pacific at the NATO front with Russia. However, the Arctic has become an important theatre in this great power competition. As the Arctic ice continues to melt, great powers continue looking at unprecedented changes. Smaller countries are looking at participating in minor ways, but it is very likely that in the next 5 years, we will see a trend in great power dynamics. Right now, for example, there are other theatres that have connections with the Arctic, so the 
main question is how can we prepare for this new situation, which has long-term implications at the strategic level? There are many issues that will arise, so we need a conceptual frame - a way to see the big picture.

\section{KEY POINTS OF DISCUSSION}

\section{Presentation}

- As Canada is becoming a peninsula state, it is the first time it is facing different great powers and finding itself in a new strategic environment.

- Peninsula states should always think about the connectivity between different ocean fronts, as they have long-term implications.

- It is paramount to be prepared for the new situations that will arise as the Arctic ice continues to melt and great power competition becomes a trend.

- Thinking of Canada as a peninsula state is a foundational concept to help us understand this new situation.

- Some of the long-term implications that Canada should start considering as it becomes a peninsula state include strategic priorities, resources allocations, and institutional configurations.

\section{Question Period}

- Arctic issues go beyond the usual actors. Japan, Iceland, Sweden, and Norway, for example, are not involved in strategic moves but are paying attention to moves made by other countries.

- Canada has been in a fortunate situation in which most of the confrontations have happened in the Western Pacific.

- As the Arctic ice continues to melt, the great power competition dynamics will become a trend and many issues will arise.

\section{c) $($ () $\ominus$}

EY NC ND This work is licensed under a Creative Commons Attribution-NonCommercial-NoDerivatives 4.0 International License.

(C) (TSUYOSHI KAWASAKI, 2022)

Published by the Journal of Intelligence, Conflict, and Warfare and Simon Fraser University

Available from: https://jicw.org/

The Journal of Intelligence, Conflict, and Warfare Volume 4, Issue 3 